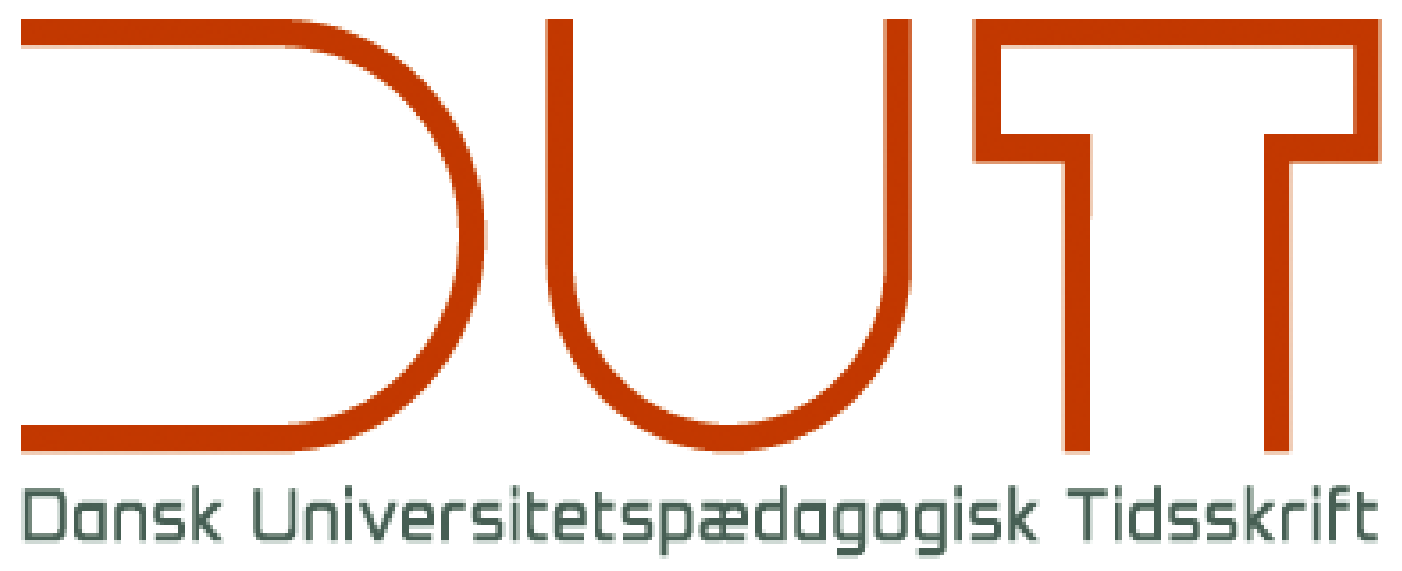

Tema

Nye perspektiver på evalueringsformer i universitetspædagogik

Årgang 12 nr. 23 / 2017

Titel

Anmeldelse: Eksamensrevolusjonen. Råd og tips om eksamen og alternative vurderingsformer

Forfatter

Arild Raaheim

Anmelder

Ole Eggers Bjælde og Annika Büchert Lindberg

Sidetal

$87-88$

Udgivet af

Dansk Universitetspædagogisk Netværk, DUN

> http://dun-net.dk/

Betingelser for brug af denne artikel

Denne artikel er omfattet af ophavsretsloven, og der må citeres fra den. Følgende betingelser skal dog være opfyldt:

- Citatet skal være i overensstemmelse med "god skik"

- Der må kun citeres „i det omfang, som betinges af formålet"

- Ophavsmanden til teksten skal krediteres, og kilden skal angives ift. ovenstående bibliografiske oplysninger. 


\title{
Eksamensrevolusjonen. Råd og tips om eksamen og alternative vurderingsformer
}

\author{
Anmeldt af Annika Büchert Lindberg og Ole Eggers Bjoelde
}

Arild Raaheim

Gyldendal Akademisk, Oslo, 2016

ISBN 9788205490819

Bogen formidler på et fængende og letlæst norsk sine to hovedformål: at formidle den nyeste viden inden for eksamen og bedømmelse af de studerende på universitetsniveau samt at inspirere til nye, alternative bedømmelsesformer.

Hovedbudskabet i bogen er, at de nuværende og traditionelle eksamens- og bedømmelsesformer har stor andel i det store karakter- og præstationsfokus, som hersker hos studerende inden for nutidens universitetsundervisning. Bogens forfatter mener således, at tiden er inde til en "eksamensrevolusjon", hvor fokus fjernes fra at kontrollere og dokumentere, og hvor eksamens- og bedømmelsesformer nytænkes og erstattes af nye metoder, som styrker studerendes læring. Det vil kræve, at vi reflekterer over den eksisterende viden inden for feltet og anvender denne til planlægning og gennemførelse af relevant undervisning, hvor der er sammenhæng mellem de studerendes læringsudbytte og bedømmelsesformerne. Bogen giver ideer til, hvordan sidstnævnte kan nytænkes, så bedømmelsen afspejler de færdigheder og kompetencer, som samfundet efterstræber, og som sikrer vore studerendes fremtidige læring.

Bogen indleder med at opfordre os til at skelne mellem bedømmelse (på norsk: vurdering) og evaluering. Bedømmelse defineres her som alle former for udprøvning af studerende (på norsk "all form for prøvning av studenter"), mens evaluering bruges om studenterevaluering af undervisning, evaluering af studieprogrammer og af uddannelsesinstitutioner. Denne opfordring er lige så relevant i Danmark som i Norge, og den er hermed videregivet.

Bogen fortsætter herefter med at forklare problemet med traditionelle eksamensformer. Et godt eksempel er forfatterens udmærkede analogi mellem en traditionel sluteksamen og et verdensmesterskab inden for sportens verden: "Det er omtrent som idrettsstjernene som konkurrerer om gull i VM. Hva de har prestert før de kommer til VM, og hvilke prestasjoner de oppnår i etterkant av VM, spiller ingen roll. Gullet deles ut til den som gjør det best akkurat der og da, når VM-øvelsen går." Passagen illustrerer på glimrende vis problemet med en højrisiko-eksamen, som 
udgør $100 \%$ af en studerendes karakter. En del af løsningen i såvel norsk som dansk regi er brugen af løbende bedømmelse, som har været muligt i Danmark siden den nyeste eksamensbekendtgørelse fra sommeren 2016. I løbende bedømmelse kan en studerendes præstationer i løbet af undervisningen bidrage til den studerendes karakter i fællesskab med en eventuel afsluttende eksamen.

Foruden at diskutere udfordringer i den traditionelle bedømmelsespraksis slår bogens forfatter desuden et slag for flere relevante og aktuelle emner inden for bedømmelsespraksis. Således er tilbagevendende emner i bogen både autentiske bedømmelsesformer og en mere gennemtænkt feedbackpraksis, som både involverer peer feedback og feedback, som direkte kan bruges til noget. Ligeledes understreges det, at en god læringsoplevelse handler om en balance mellem graden af udfordring og oplevelsen af at være kompetent. Det er sagens kerne - ikke antallet af arbejdstimer brugt per studerende.

Desuden diskuterer bogens forfatter forskellige årsager til eksamenssnyd, samt hvilke løsninger forfatteren ser. Det understreges, at den nuværende bedømmelsespraksis er en del af problemet, og en del af løsningen er nye bedømmelsesformer. Og mens vi alligevel er i gang med at nytænke, hvorfor så ikke bruge teknologi til at innovere både bedømmelses- og undervisningspraksis fuldstændig.

I den sidste del af bogen gennemgår bogens forfatter en række mere eller mindre alternative bedømmelsesformer, som kan fungere som inspiration til undervisere, som ønsker at tage del i "eksamensrevolusjonen". Og herfra skal der lyde et kampråb til støtte for "revolusjonen", som også så småt er i gang herhjemme. 